\title{
FENOMENA KEKERASAN TERHADAP ANAK DI KOTA AMBON
}

\author{
Handry Piris
}

\begin{abstract}
Violence ia a social phenomenon that appears without any end. Violence in the social context is motivated by various problems. Political issues, economic, law, social disharmonization, SARA, ethics environment, cultural issues are often the tringger of violence.in the context of this paper, violence to the child to be a major concern. Because of the child is the grace of God in the deposit to a family, through a holly marriage bond, with the responsibility to educate, maintain a child of good qualities both physically and spiritually.From this context "as if" for some of the children's society "no/less" is seen as a gift and a gift of God in a family. Therefore child has always been a object to a violent acts on the basis and motifs diverse child tend to be exploited for the benefit and spesific needs of adult.Children are heirs to a new generation. As the holder of inheritance rights to a new generation, the child should be treated "special"both from the physical and the spiritual aspects. Violece againts children is a manifestation of character assasionation against a generation's inheritance heirs. The phenomenon of violence in Ambon is a form of massive injustice. So that it must get serious attantion from all ellements of society. Issues of economic, education and law enforcement should be fundamental to government and religious institutions. On the other hand the role of the family as the first bastion in blocking the violence to the child must be maximized, accompanied also by the role of society in general as the second fort.
\end{abstract}

Keywoords: Violence, Child, Role, Parents, Injustice

\begin{abstract}
Abstrak
Kekerasan adalah sebuah fenomena sosial yang seakan muncul tanpa ada ujungnya. Kekerasan dalam konteks sosial dilatarbelakangi oleh berbagi masalah. Masalah politik, hukum, ekonomi, disharmonisasi relasi sosial, SARA, etika lingkungan, masalah budaya seringkali menjadi cikal bakal terjadinya kekerasan. Dalam konteks tulisan ini kekerasan kepada anak menjadi perhatian utama karena anak merupakan anugerah Allah yang ditiitpkan kepada sebuah keluarga, dalam sebuah ikatan pernikahan yang kudus, dengan tanggung jawab untuk mendidik, menjaga/memelihara menjadi anak yang berkualitas baik dari sisi jasmani maupun rohani. Dari konteks ini "seakan" bagi sebagian masyarakat anak "tidak/kurang" dipandang sebagai anugerah dan titipan Allah dalam sebuah keluarga. Oleh karena itu anak selalu menjadi objek untuk sebuah tindakan kekerasan atas dasar dan motif yang beragam. Anak cenderung dieksploitasi untuk kepentingan dan kebutuhan tertentu dari orang dewasa. Anak merupakan pewaris terhadap sebuah generasi baru. Sebagai pemegang hak waris terhadap sebuah generasi baru, seharusnya anak mendapat perlakuan yang "istimewa" baik dari aspek jasmani maupun rohani. Kekerasan terhadap anak adalah sebuah wujud nyata pembunuhan karakter terhadap pemegang hak waris sebuah generasi. Fenomena kekerasan di Ambon adalah sebuah bentuk ketidakadilan yang masif, sehingga daripadanya harus mendapat perhatian serius dari semua elemen masyarakat. Persoalan pendidikan, ekonomi serta penegakan hukum
\end{abstract}


haruslah menjadi konsentrasi pemerintah dan lembaga keagamaan. Dilain sisi, peran keluarga sebagai benteng pertama dalam menghadang kekerasan kepada anak harus maksimal, disertai juga dengan peran masyarakat secara umum sebagai benteng kedua.

Kata Kunci: Kekerasan, Anak, Peran, Orang Tua, Ketidakadilan.

\section{PENDAHULUAN}

Kondisi umum di Indonesia memperlihatkan bahwa fenomena kekerasan dalam ruang publik berlangsung secara terus menerus dari waktu ke waktu. Dari aspek sosiologis, di Indonesia kekerasan terjadi dalam berbagai bentuk, dan dilatarbelakangi oleh berbagai persoalan dan kepentingan serta melibatkan berbagai kalangan. Fenomena kekerasan dalam ruang sosial di Indonesia biasanya terjadi karena "ada kekuatan mayoritas yang mengklaim diri sebagai yang berkuasa", dan oleh karena itu, semua segmen kehidupan harus menghormati nilai nilai kelompok (kekuatan mayoritas) tersebut. Namun, hal yang paling naif adalah penggunaan "kekuatan/kekuasaan yang dimiliki oleh kelompok (kuat) itu, adalah untuk kepentingan dan kesenangan pribadi dan kelompok yang kemudian harus mengorbankan hak hak orang lain (mereka yang dianggap lemah).

Hal lain juga, bahwa kekerasan yang terjadi selain mengarah pada lapisan masyarakat yang "minoritas", tetapi juga mengarah pada kelompok-kelompok yang dianggap "tidak biasa" atau "tidak sama" "lemah", baik secara struktural maupun fungsional.

Melalui data yang diperoleh dari beberapa sumber, pergerakan kekerasan yang terjadi dari tahun ke tahun mengalami peningkatan yang signifikan. Dari data pengaduan masyarakat ke Komisi Perlindungan Anak Indonesia (KPAI) dalam 7 tahun terakhir, ditemukan 26.954 kasus kekerasan kepada anak dengan 9 klaster dan 3 klaster di antaranya yang paling tinggi. ${ }^{1}$

Dalam konteks Maluku kekerasan terhadap anak, sangat sering sekali kita jumpai dalam realita sosial. Dari perspektif sosio-kultural sebagian masyarakat Maluku (terutama didaerah yang masih tertinggal dalam aspek pendidikan),

Kekerasan fisik kepada anak dianggap bukan merupakan sebuah pelanggaran terhadap hukum, lebih jauh bahwa kekerasan yang dilakukan oleh 
orang dewasa kepada anak dipersepsikan sebagai sebuah cara mendidik anak agar taat pada orang tua. Dalam beberapa kasus di desa/negeri dalam wilayah kota Ambon, sampai sejauh ini bentuk didikan dengan menggunakan kekerasan (memukul dengan rotan, tempeleng, dicubit atau dijewer telinga dsb., masih dianggap biasa, dan wajar).

Masih pada daerah kota Ambon dan sekitarnya tercatat dari tahun 2016 periode Januari sampai Agustus sebanyak 48 kasus ditangani oleh unit Pelayanan Perempuan dan Anak (PPA) Satreskrim Polres Ambon. Melalui data PPA itu disebutkan bahwa kasus percabulan dan perkosaan dengan kekerasan terhadap anak mengalami peningkatan dibandingkan dengan tahun sebelumnya. ${ }^{2}$ Mirisnya adalah hampir sebagian besar kasus kekerasan kepada Anak Indonesia termasuk di Ambon dilakukan oleh orang terdekat.

Bila dilihat dari kategorisasi dan klasterisasi kekerasan terhadap anak yang terjadi di kota Ambon, maka Ambon masuk pada kategori/klaster a,b c dan d. Lih. Diagram KPAI. (klaster 1)

Data KPAI 2014-2017

\begin{tabular}{|c|c|c|c|c|c|c|}
\hline \multirow{2}{*}{ NO. } & \multirow[t]{2}{*}{ KLASTER /BIDANG } & \multicolumn{4}{|c|}{ TAHUN } & \multirow[b]{2}{*}{ Jumlah } \\
\hline & & 2014 & 2015 & 2016 & 2017 & \\
\hline 1 & Kekerasan fisik & 126 & 110 & 291 & 142 & \\
\hline 2 & Kekerasan psikis & 49 & 27 & 127 & 41 & \\
\hline 3 & Kekerasan seksual, & 329 & 746 & 590 & 621 & \\
\hline 4 & Pembunuhan & 50 & 132 & 127 & 168 & \\
\hline 5 & Penculikan & 32 & 75 & 68 & 48 & \\
\hline 6 & Bunuh diri & 12 & 35 & 17 & 23 & \\
\hline 7 & Kecelakaan Lalu lintas & 14 & 161 & 97 & 76 & \\
\hline 8 & Aborsi & 6 & 9 & 19 & 28 & \\
\hline 9 & Penganiayaan/pengeroyokan & 61 & 32 & 22 & 74 & \\
\hline
\end{tabular}

Di tahun 2017 pada kota Ambon, data kekerasan dari PPA dengan klaster 1 (fisik, psikis, seksual dan pembunuhan) tercatat sebanyak 37 kasus. Hampir semua kasus 
ini melibatkan anak dari rentang umur 15 tahun ke bawah dan menjadi korban adalah anak anak perempuan. ${ }^{3}$

Sisi lain dari kasus kekerasan kepada anak di wilayah kota Ambon sebagaimana data yang telah saya jabarkan diatas adalah: keterlibatan orang terdekat. Baik itu orang tua kandung/wali, kenalan, paman, bibi dan sebagainya. Kondisi ini sangatlah memprihatinkan dan merupakan sebuah gambaran besar betapa anak anak dalam wilayah ini hidup dalam ancaman besar dan nyata yang sampai saat ini belum ada upaya konkret untuk menyelesaikannya. Pendekatan hukum terhadap pelaku tindak kekerasan anak sejatinya menurut saya bukanlah satu satunya sebuah upaya konkret dalam menyelesaikan masalah kekerasan terhadap anak. Perlu pendekatan yang lebih komprehensif, sebab tindakan kekerasan terhadap anak ini muncul dengan dilatarbelakangi oleh berbagai persoalan. Persoalan ekonomi, pendidikan, persoalan sosial bahkan politik. Tentunya perlu analisis dan pendekatan yang komprehensif pula.

Dapat diduga bahwa terdapat kesenjangan yang tajam dalam realita sosial di kota Ambon antara miskin dan kaya, kuat dan lemah, dan itu juga merupakan bagian yang tidak terpisahkan dari munculnya kekerasan terhadap anak. Hal ini tentu saja menjadi sebuah kegelisahan kita bersama yang harus dijawab demi keadilan sosial bagi seluruh masyarakat, terutama anak-anak di kota Ambon.

\section{PEMBAHASAN}

\subsection{Aspek Sosio-Kultural: Apakah sebagai Jembatan Kekerasan di Ambon}

Tidak bermaksud untuk menjustifikasi aspek sosio-kultural masyarakat kota Ambon sebagai masyarakat yang "keras"(brutalism), tetapi bagi saya penting sekali untuk melihat tatanan sosio-kultural masyarakat kota Ambon yang ada ini, dalam upaya untuk menemukan poin point penting, terutama tentang seberapa besar aspek-sosio kultural masyarakat kota Ambon ini memberikan sumbangsih terhadap munculnya "kekerasan" kepada anak. 


\subsubsection{Masyarakat Kota Ambon Sebagai Masyarakat "Keras"}

Pada umumnya masyarakat kota Ambon ini adalah masyarakat plural/majemuk. Masyarakat yang terdiri dari beragam agama, etnis, sub-etnis suku, ras bahkan berasal dari campuran keturunan bangsa lain di dunia. Sebagai kota yang masyarakatnya plural/majemuk, tentu saja menjadi sebuah keunikan, kekuatan bahkan kebanggaan tersendiri bagi masyarakat kota Ambon. Namun di lain sisi kepelbedaan suku,ras, etnis agama dan lain lain bisa menimbulkan berbagai persoalan dan gejolak sosial dalam masyarakat kota Ambon itu sendiri apabila tidak dikelola dengan baik. Peristiwa 99 konflik horisontal (SARA), adalah contoh bagaimana kekerasan dapat dengan mudah terjadi di kota ini serta peristiwa peristiwa kekerasan lainnya yang justru terjadi karena persoalan persoalan sepele.

Mengapa kekerasan ini terjadi, salah satu hal yang muncul dari konteks kekerasan di maluku adalah "adanya sebuah upaya untuk mempertahankan eksistensi dan jati diri dari "etnisitas tertentu". Dalam konteks ini, sebagaimana struktur eksistensilisme mengatakan bahwa : eksistensialisme lebih berpusat pada manusia secara individu-yang bertanggung jawab atas kemauannya yang bebas tanpa memikirkan secara mendalam mana yang benar dan mana yang tidak benar, tetapi sadar bahwa kebenaran bersifat relatif dan karenanya masing-masing individu bebas menentukan sesuatu yang menurutnya benar. ${ }^{4}$

Menurut Th van Den End. Sejarah "kekerasan” yang terjadi di Maluku Selatan sudah berlangsung sejak lama. Hal ini berkaitan dengan perselisihan perselisihan lokal antar kampung, antar perkelompokan dll. ${ }^{5}$ Artinya apa? Dari aspek sosio -historis, masyarakat Maluku (kota Ambon) sudah "memiliki" karakter tersendiri. Karakter sebagai petarung untuk menancapkan superioritasnya terhadap kelompok lain, bahkan terhadap individu lainnya.

Lalu di manakah hubungannya dengan kekerasan yang terjadi dewasa ini, terutama kepada anak-anak? Kita pahami persis bahwa kelompok anak anak dalam konteks sebagian masyarakat Maluku/Kota Ambon, belum menduduk posisi penting dalam relita sosial. Di sisi lain anak anak adalah kelompok yang 
lemah secara fisik, maupun psikis dibandingkan dengan kelompok manusia lainnya. Faktor inilah yang kemudian menurut saya memunculkan sikap superioritas terhadap kelompok anak-anak yang dianggap inferior (lemah).

Pada sisi lain, pola patriakhal dalam sistem sosial masyarakat Maluku, menurut saya juga memberikan peran yang kuat terhadap dominasi laki-laki pada perempuan bahkan juga terhadap anak-anak (terutama anak perempuan). Dalam beberapa hal kaum perempuan di Maluku ada pada posisi inferior. Walaupun dari sisi peran, perempuan Maluku (Chirstina Marta Tiahahu dll.) sudah selevel dengan laki laki. Hal ini mengindikasikan bahwa peran perempuan yang setara dengan laki-laki, belumlah cukup menjadi barometer kesetaraan di Maluku (kota Ambon). Diskriminasi terhadap kaum perempuan di Maluku cenderung cukup signifikan dibandingkan dengan daerah daerah lain di Indonesia kecuali Papua. Realitas ini menggambarkan secara linear bagaimana kekerasan terjadi kepada anak-anak dengan dilatarbelakangi oleh prinsip superioritas maupun konsep patriakhal yang cenderung sempit.

\subsubsection{Masyarakat Kota Ambon dan Masalah Sosialnya}

Ketika kita berbicara tentang konsep masyarakat kota, maka sedikit mengutip pikiran dari sekum GPM, E. Maspaitella, bahwa kota adalah jantung dari sebuah perubahan masyarakat, dan sebagai tempat bersaing (social competition). Persaingan sosial bisa meliputi beberapa aspek. Salah satu aspek yang perlu menjadi perhatian adalah: masalah ekonomi dan kesejahteraan, serta pendidikan.

Kita dapat melihat bahwa dalam konteks sosio-ekonomi, kota Ambon memiliki karakteristik tersendiri. Sebagian besar penduduk bergerak pada sektor industri dan ekonomi kreatif menengah ke bawah. Sementara di wilayah pulau Ambon hampir sebagian besar penduduknya bekerja sebagai petani dan nelayan. Pada sisi yang lain, untuk kesenjangan kesejahteraan, masih merupakan problematika pemerintah kota Ambon. Bahwa ada kesenjangan yang luas antara kesejahteraan sebagian masyarakat yang berprofesi sebagai "penggerak ekonomi kreatif' (tukang becak, buruh bangunan, buruh bagasi pelabuhan, tukang parkir dan yang sejenisnya dibandingkan dengan yang berprofesi sebagai PNS, Pengusaha menengah keatas, TNI, Polri, Pegawai Swasta dll. Adalah realita yang 
tidak dapat diabaikan begitu saja dalam pengamatan kita. Hal ini penting untuk diurai, mengingat dari kesenjangan yang ada ini, berdampak atau melahirkan problematika sosial dalam masyarakat secara universal.

Secara teoritis, kesenjangan sosial adalah suatu keadaan sosial masyarakat

yang berada pada kondisi ketidakseimbangan. Kesenjangan dan ketidakseimbangan ini terjadi karena ada kesalahan fungsi dan kedudukan anggota masyarakat ${ }^{6}$. Dalam realita masyarakat, kesenjangan sosial dapat menimbulkan konflik, karena dapat memunculkan kecemburuan dan anggapan diskriminatif atau pembatasan hak masyarakat untuk memperoleh kesejahteraan. Oleh sebab itu dapat disimpulkan bahwa kesenjangan sosial merupakan salah satu akar penyebab timbulnya kericuhan, kesalahpahaman dan kekerasan.

Sejalan dengan konsep di atas - sebagaimana data yang disampaikan memperlihatkan bahwa kasus kekerasan kepada anak, yang terjadi di Ambon selain dilakukan oleh orang-orang terdekat tetapi juga banyak dilakukan oleh mereka yang tingkat ekonomi serta pendidikan yang rendah. Tingkat pendidikan yang rendah sangat dipengaruhi oleh faktor ekonomi. Olehnya menurut saya, kesejangan yang terjadi harus menjadi perhatian khusus sebab dari kesenjangan tersebut akan melahirkan disharmonisasi sosial dan dapat berujung pada menculnya penyakit sosial dalam masyarakat berupa kekerasan fisik, psikis dll.

\subsubsection{Fenomena Kekerasan terhadap Anak di Kota Ambon - Sebuah Fakta Sosial.}

\section{a. Menelisik Kasus Perkosaan 17 Oktober 2017}

Masyarakat kota Ambon pada tahun 2017 baru saja dikejutkan dengan sebuah peristiwa yang sangat miris. Kasus kekerasan dan pemerkosaan terhadap anak berumur kira kira 8-10 tahun oleh ayah kandungnya sendiri. Menurut data yang dilansir oleh Humas Mapolres P. Ambon dan P.P.Lease, kejadian kekerasan dan pemerkosaan terhadap anak kandung ini terjadi pada selasa 17 Oktober 2017 sekitar pukul 05.00 WIT disekitar Bank BCA Jl.Pantai Mardika, Kelurahan Batu Merah-Kecamatan Sirimau Kota Ambon. Kejadian ini disinyalir berlatarbelakang pelampiasan nafsu orang tua kandung karena sudah ditinggal cerai oleh istrinya. 
Yang menarik adalah perlakuan pemerkosaan, pencabulan dengan kekerasan ini sudah dilakukan oleh oknum kepadanya anaknya secara berulang-ulang. Selain dari kondisi ini, oknum pelaku memerkosa anakanya dipagi jam 03.30 wit, serta menelantarkan anaknya itu di emperan toko dengan berlumuran darah.

Menurut data dari PPA Satreskrim Pelres Kota Ambon, persitiwa ini dilatarbelakangi oleh keinginan orang tua korban untuk melampiaskan nafsu birahinya, yang sejak beberapa bulan tidak tersalurkan akibat dari tidak ada istrinya. Pelaku sebelum melakukan aksinya, terlebih dahulu mengonsumsi minuman keras. Sebagai seorang penarik becak pelaku memang memiliki masalah dengan hubungan rumah tangganya. Apakah persoalan ekonomi, atau relasi disharmonisasi rumah tangga yang tidak terjalin baik, tetapi faktanya bahwa istrinya telah beberapa bulan meninggalkan pelaku.

Inilah sebuah potret buram realita sosial di kota Ambon terhadap eksisitensi anak. Dari data dan penjelasan yang ada ini, kita dapat melihat bahwa begitu mudahnya orang tua melakukan aksi yang tak beradab kepada anak kandungnya.

\section{b. Disharmonisasi Keluarga sebagai Salah Satu Faktor Pemicu Kekerasan}

\section{kepada Anak}

Keluarga adalah unit terkecil dari mayarakat. Keluarga terdiri atas kepala dan beberapa orang yang berkumpul dalam suatu atap dengan fungsi saling beketergantungan, saling berhubungan melalui pertalian darah. ${ }^{7}$

Dalam beberapa teori keluarga disebutkan bahwa aspek aspek disharmonisasi keluarga dapat digambarkan sebagai berikut ;

- Kurangnya kasih sayang antar keluarga, bahwa kasih sayang merupakan kebutuhan manusia yang paling hakiki. Sebab semenjak lahir manusia sudah membutuhkan kasih sayang dari sesama. Namun bila dalam sebuah keluarga tidak terjalin hubungan yang harmoni, maka dipastikan tidak akan terjalin hubungan emosional yang harmoni antar satu dengan yang lainnya. 
- Tidak berlangsung dialog yang korelasional. Dengan tidak adanya dialog yang korelasional, maka dapat dipastikan masing-masing anggota keluarga tidak akan mengetahui apa yang menjadi persoalan utama. ${ }^{8}$

Dalam konteks kasus yang dialami oleh bocah 8 tahun di Ambon tadi, mengindikasikan bahwa kasih sayang dari orang tua terhadap anak megalami "kecacatan akut". Kasadaran orang tua untuk dalam memahami siapa dirinya mengalami "kecacatan". Ia tidak lagi mengetahui siapa ia, lalu bagaimana ia harus bertindak sebagai seorang ayah terhadap anaknya. Benar bahwa sebagai seorang single parent ia mempunyai tantangan yang lebih besar dalam membina rumah tangganya itu. Tetapi ia gagal untuk mengambil peran sebagai single parent.

\section{c. Konteks Alkitab Tentang Keluarga}

Secara umum Alkitab memberikan penjelasan yang utuh tentang siapakah anak itu dalam sebuah keluarga. Alkitab menjelaskan bahwa Allah telah memberikan perempuan kepada laki laki itu untuk menjadi teman yang sepadan. Mereka hidup dalam pernikahan yang suci, sehingga dapat berkembang biak. Oleh sebab itu, anak dapat dikatakan sebagai berkat istimewa (Kej.1 :28), Allah memberkati mereka lalu berfirman kepada mereka "beranak cuculah dan bertambah banyak; penuhilah bumi dan taklukanlah itu, berkuasalah atas ikan ikan dilaut, dan burung burung di udara dan atas segala binatang yang merayap dibumi. Jelaslah bahwa Allah memberkati sebuah perkawinan, dan kemudian memerintahkan mereka agar berkembang biak dan memenuhi bumi. Oleh sebab itu maka keturunan adalah bagian dari berkat Allah ${ }^{9}$.

Maka dapat dipastikan bahwa anak adalah karunia Tuhan kepada orangtua yang telah bersatu dalam wadah perkawinan Kristen. Allah menitipkan anak kepada orang tua, namun anak itu sendiri adalah milik Tuhan. Sebab dialah yang menciptakan manusia termasuk anak anak kita.

Jadi, jika kita menyadari bahwa anak adalah titipan Allah kepada manusia dewasa, maka tugas untuk menjaga dan memelihara anak semestinya lebih besar 
dan tertanggung jawab. Sebab mendidik dan merawat anak haruslah dilihat sebagai tanggung jawab dan kewajiban yang mulia dan agung.

Dalam teks-teks lain di dalam Alkitab terkhususnya di dalam Perjanjian Baru (Matius 19 : 14-15) "biarkanlah anak anak itu, jangan menghalang halangi mereka datang kepadaKu; sebab orang orang yang seperti itulah yang empunya kerajaan sorga. Lalu Ia meletakan tanganNya atas mereka dan kemudian ia berangkat dari situ.

(Markus 10 : 13 - 16). Lalu orang membawa anak-anak kecil kepada Yesus, supaya Ia menjamah mereka; akan tetapi murid-murid-Nya memarahi orang orang itu. Ketika Yesus melihat hal itu, ia marah dan berkata kepada mereka : "Biarkanlah anak-anak itu datang kepadaKu, jangan menghalang halangi mereka, sebab orang orang yang seperti itulah yang empunya kerajaan Allah. Aku berkata kepadamu: sesungguhnya barangsiapa tidak menyambut kerajaan Allah seperti seorang anak kecil, ia tidak akan masuk kedalamnya”. Lalu Ia memeluk anak-anak itu dan sambil meletakan tanganNya atas mereka Ia memberkati mereka.

(Lukas : $18: 15$ - 17). Maka datanglah orang-orang membawa anakanaknya yang kecil kepada Yesus, supaya ia menjamah mereka. Melihat itu murid-muridNya memarahi orang-orang itu. Tetapi Yesus memanggil mereka dan berkata: "biarkanlah anak-anak itu datang kepada-Ku dan jangan kamu menghalang-halangi mereka, sebab orang-orang seperti itulah yang empunya kerajaan Allah. Aku berkata kepadaMu : sesungguhnya barangsiapa tidak menyambut kerajaan Allah seperti seorang anak kecil, ia tidak akan masuk kedalamnya.

Tiga teks Injil dalam Perjanjian Baru ini, dari perspektif hemeneutik, dengan pendekatan - historis kritis memang lebih menyentuh tentang hal "kerajaan sorga", dengan menampilkan anak anak sebagai sampel. Tentunya dengan dasar bahwa anak anak lebih cenderung memiliki sifat yang patuh pada orang tua, polos, cenderung tidak menyimpan dendam atas kesalahan temannya dan seterusnya. Inilah dasar utama muatan teologis terkait dengan hal kerajaan sorga.

Dari aspek sosiologis, baik Matius, Markus, maupun Lukas juga memilih untuk melihat anak-anak pada waktu itu sebagai orang yang tidak memiliki 
banyak peran penting dalam masyarakat Yahudi dan cenderung diabaikan hak-hak hidupnya. Entah itu dalam kaitannya dengan kehidupan sosial, ekonomi, kultural, bahkan aspek keagamaan sekalipun. Kondisi ini kemudian melahirkan segragasi sosial dalam masyarakat Yahudi dan menempatkan anak anak sebagai kelompok yang termarginalkan. Oleh sebab pendekatan kritik sosial dari Matius, Markus maupun Lukas, dengan memperlihatkan Yesus sebagai agen perubahan, maka Yesus kemudian memposisikan kedudukan anak-anak dalam realita sosial masyarakat Yahudi sebagai bagian yang "sangat penting" dengan sebuah kritik tajam kepada murid muriNya yang saat itu menghalang halangi anak anak yang datang kepadaNya. Yesus mengatakan bahwa mereka (anak-anak) inilah yang empunya kerajaan sorga. Inilah sebuah kritik sosial Yesus terhadap realitas sosial yang justru ditujukan kepada orang terdekatNya (murid-murid). Dalam konteks ini sesungguhnya, perlakuan diskriminatif yang ditampilkan oleh para murid tentu saja dilatarbelakangi oleh sistim sosial yang berlaku saat itu dalam konteks orang Yahudi. Sistim patriakhal dalam realita kultural masyarakat Yahudi, dipahami secara pragmatis, dan berlaku tanpa batasan tertentu. Sesungguhnya sistim patriakhal yang terutama "hanya" mengatur garis keturunan ego, justru dipahami dalam batasan yang lebih luas (sampai pada aspek aspek sosial, bahkan keagamaan). Oleh sebab itu, Yesus melihat bahwa ada kesalahan pandangan dari masyarakat Yahudi termasuk orang dekatnya (murid - murid).

Sejalan dengan itu, mau dikemukakan beberapa hal penting, tentang bagaimana sesungguhnya sikap yang seharusnya dipunyai oleh orang tua terhadap anak anak.

1. Anak anak merupakan titipan Allah kepada orang tua, untuk menjaga dan memelihara serta memberikan pendidikan yang baik. Olehnya mengabaikan tugas untuk menjaga, memelihara dan memberikan pendidikan yang baik kepada anak, sama halnya dengan mengabaikan tugas yang diberikan Allah kepada orang tua.

2. Anak anak mempunyai posisi sosial dalam masyarakat yang sama dengan orang lain. Karena kesamaan itulah maka mereka harus diperlakukan sama dengan orang lain. Tidak harus ada diskriminasi kepada mereka karena fakta fakta pragmatis yang melekat pada diri mereka (secara fisik mereka lemah, psikologis mereka yang labil dsb.). 
3. Eksploitasi anak untuk kepentingan dan keinginan serta kebutuhan orang dewasa adalah, suatu bentuk kemurkaan manusia terhadap perintah Allah. Inilah sesungguhnya bentuk kejahatan di mata Allah.

\section{KESIMPULAN}

Kota Ambon sebagai salah satu kota sedang di Indonesia dengan tingkat pertumbuhan berbagai sektor kehidupan yang cukup pesat memberikan angin segar kepada setiap penduduknya peluang, harapan bahkan tantangan dan pergumulan tersendiri. sebagai kota yang sedang berkembang pesat, kota Ambon membuka begitu banyak pintu lapangan pekerjaan bagi masyarakatnya. Tetapi pada sisi itu perkembangan kota modern ini tentu saja harus melibatkan orang orang yang memiliki kompetensi yang memadai. Sebab tanpa kompetensi yang memadai, dapat dipastikan bahwa mereka akan tersisih dari persaingan mencari lahan pekerjaan. Sebagaimana sebagian masyarakat kota yang akhirnya harus memilih berprofesi sebagai tukang becak, adalah mereka yang "dianggap tersisih" dari ketatnya persaingan mencari lahan pekerjaan di kota ini. Secara umum mereka yang berprofesi sebagai tukang becak sekarang ini memiliki latar belakang pendidikan SMA kebawah. Artinya dari segi kompetensi mereka ini "kalah" bersaing dibandingkan dengan mereka yang lulusan s1 ke atas.

Fenomena kekerasan yang terjadi di kota Ambon hampir 90 persen dilakukan oleh oknum yang memiliki latar belakang keluarga "bermasalah" terutama dalam relasi keluarga, dengan medium ekonomi dan pendidikan. Artinya apa? Faktor ekonomi dan pendidikan hanyalah sebuah akumulasi dari kesenjangan relasi sosial dalam masyarakatnya.

Secara eksplisit masalah kekerasan terhadap anak di pulau Ambon dapat dicermati melalui beberapa pendekatan;

\section{a. Aspek sosio - kultural.}

Sebagaimana yang dikemukakan oleh Th.Van den End, bahwa pertikaian antar kelompok maupun perorangan, sudah berlangsung di Maluku sejak lama. Sebagai daerah yang memiliki topografi alam yang terdiri dari pegunungan dan lembah yang curam, disertai dengan kondisi alam yang cukup menantang, masyarakat Maluku umumnya harus memiliki “jiwa petarung”. Jiwa petarung 
untuk menaklukan alam (laut maupun darat), tetapi juga jiwa petarung untuk menaklukan musuh demi kelangsungan hidup. Pada sisi lain kondisi wilayah yang terdiri dari kerajaan kerajaan kecil memungkinkan terjadi pertentangan untuk penaklukan wilayah kekuasaan. Selain itu juga eksistensi identitas (sub suku, maupun agama) menjadi dasar utama kenapa masyarakat di Maluku cenderung terlibat dalam kekerasan antar dominasi dan kelompok.

Penggunaan kekuatan fisik (kekerasan) dan kekuasaan dalam penyelesaian suatu masalah di Maluku pada "era itu" secara umum dan secara khusus di Ambon, sepertinya menjadi pilihan yang utama mereka dalam "menuntaskan" suatu masalah.

\section{b. Aspek pendidikan dan Pengetahuan}

Mencermati tindak kekerasan terhadap anak di Ambon, secara umum, memperlihatkan bahwa tingkat pendidikan cukup signifikan memengaruhi perilaku orang tua terhadap anak. Hampir dapat dipastikan bahwa orang tua yang terlibat kekerasan kepada anak (fisik, seksual) memiliki tingkat pendidikan yang rendah. Lulusan SMA kebawah, dan bahkan tidak bersekolah. Artinya apa? Ternyata pendidikan formal memiliki korelasi yang tajam dengan perilaku kekerasan. Pendidikan formal ternyata memberikan banyak kontribusi teori pada seseorang, khususnya mengenai perilakunya di masyarakat. Tidak terkecuali juga dengan pengelolaan tindak kekerasan kepada anak.

Di lain sisi, bahwa pengetahuan juga berdampak pada perilaku seseorang dalam masyarakat. Kita tahu bersama bahwa era globalisasi telah merubah wajah dunia hampir disemua sektor kehidupan. Informasi, komunikasi dan teknologi yang berkembang pesat, memberikan kemudahan bagi masyarakat dalam mengakses berbagai informasi. Bisa melalui media visual maupun reading teks. Dewasa ini, manusia dapat mengakses berbagai macam laman dan situs dengan begitu mudah. Harusnya kemajuan di era globalisasi ini, memberikan kontribusi positif bagi masyarakat. Namun, tantangan dalam era globalisasi juga besar sekali apabila kesiapan masyarakat untuk memfilter berbagai berita dan situs internet yang tidak didasari oleh semangat membangun yang positif. Situs-situs pornografi dan dan tindak kekerasan yang diakses dari internet, terkadang menjadi insparing dari sebagian masyarakat untuk melakukan tindak kekerasan (terutama kepada 
anak). Kecenderungan tindak kekerasan kepada anak di kota Ambon melalui data yang ada, $40 \%$ terinspirasi dari film porno yang diuggah dari ponsel android. Salah satu indikasi tata kelola kemajuan teknologi yang tidak konstruktif dan pasif.

\section{c. Aspek Religiusitas}

Ada beberapa hal penting yang perlu untuk diperhatikan :

Karena anak-anak itu merupakan titipan Allah kepada orang tua, untuk menjaga dan memelihara serta memberikan pendidikan yang baik. Olehnya mengabaikan tugas untuk menjaga, memelihara dan memberikan pendidikan yang baik kepada anak, sama halnya dengan mengabaikan tugas yang diberikan Allah kepada orang tua.

Anak anak mempunyai posisi sosial dalam masyarakat yang sama dengan orang lain. Karena kesamaan itulah maka mereka harus diperlakukan sama dengan orang lain. Tidak harus ada diskriminasi kepada mereka karena fakta fakta pragmatis yang melekat pada diri mereka (secara fisik mereka lemah, psikologis mereka yang labil dsb).

Eksploitasi anak untuk kepentingan dan keinginan serta kebutuhan orang dewasa adalah, suatu bentuk kemurkaan manusia terhadap perintah Allah. Inilah susungguhnya bentuk kejahatan di mata Allah.

\section{Endnotes:}

1. Dikutip dari redaksi Ameks melalui postingan dalam Metro Manise, pada tanggal 20 September 2017, Pkl. 00.22 WIT

2. Dikutip dari http://www.psikologizone.com/psikologieksistensialisme, diakses pada tanggal..

3. Th. Van den End, 2015. Ragi Carita 1-gereja di Indonesia Tahun 1500-1850 - an : (Jakarta: BPK Gunung Mulia, 2015), hlm. 38.

4. Egi Prasetya (ed) dalam Talcott Parsons: Tinjauan Filosofis kesenjangan Sosial di IndonesiaBerdasarkan teori Sisten Sosial telcott Parsosns Jogya makalah pascasarjana UGM 2016, hlm. 4.

5. (http//www.who.com. diakses pada tanggal 15 desember 2017), Pkl. $17.00 \mathrm{WIT}$

6. Robert Boelkhe, Sejarah Perkembangan pikiran dan praktek pendidikan Agama Kristen, (Jakarta BPK Gunung Mulia, 2000), hlm. 73.

7. Harianto GP. Pendidikan Agama Kristen dalam Alkitab dan Dunia Pendidikan Masa Kini, (Jakarta : Andi Publisher, 2014), hlm. 37.

8. Paul Kniter, Satu Bumi Banyak Agama, (Jakarta: BPK Gunung Mulia, 2015), hlm. 54

9. C. Groenan, Pengatar perjanjian Baru, (Jakarta: BPK Gunung Mulia, 2016), hlm. 104. 


\section{DAFTAR PUSTAKA}

Ahmad Sahroji Data KPAI - Kekerasan Kepada Anak. Artikel KPAI Selasa 21 November 2017.

Egi Prastyo (ed). 2016. Tinjauan Filosofis di Indo :berdasarkan Teori Sistim Sosial - Talcott Parsons. Yogyakarta: Pascasarjana UGM.

Harianto GP. 2014. Pendidikan Agama Kristen dalam Alkitab dan Dunia Pendidikan Masa Kini, Jakarta: Andi Publisher.

Robert Boelkhe, 2000. Sejarah Perkembangan pikiran dan praktek pendidikan Agama Kristen, Jakarta: BPK Gunung Mulia.

Th. Van den End. 2015. Ragi Carita 1-gereja di Indonesia Tahun 1500-1850 an, Jakarta: BPK Gunung Mulia.

\section{ARTIKEL}

Dikutip dari redaksi Ameks melalui postingan dalamMetro Manise 20 September 2017

Data dari PPA Satreskrim Polres Kota Ambon 2017. Dikutip dari Kabar Timur.co.id.

http//www.who.com. diakses pada tanggal 15 desember 2017. Jam 05.00 http://www.psikologizone.com/psikologieksistensialisme 